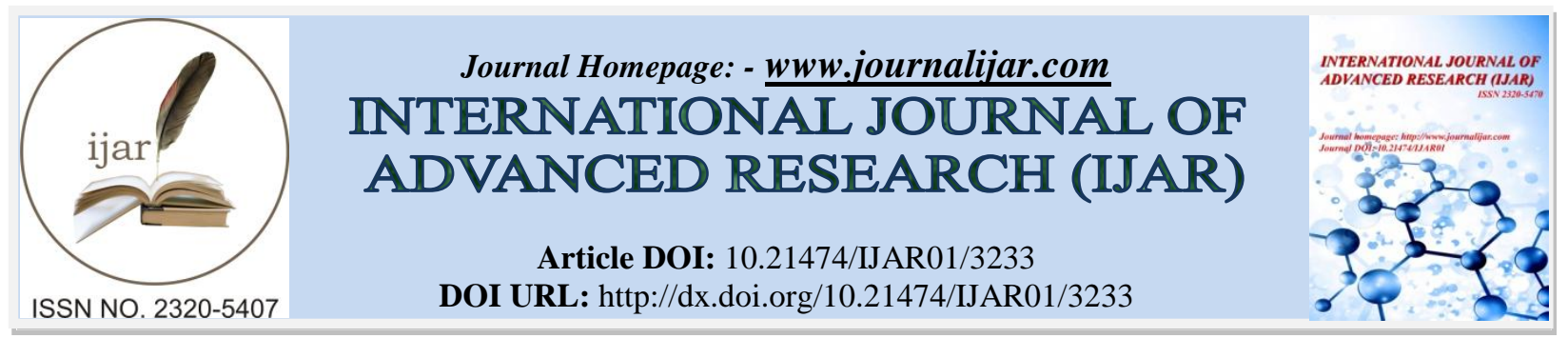

RESEARCH ARTICLE

\title{
THE STATUS OF THE GENUS ROTALA L. (LYTHRACEAE) AND DESCRIPTION OF A NEW SPECIES FROM KERALA, INDIA.
}

M.P. Rijuraj, M. Rajendraprasad, T. Shaju and A.G. Pandurangan.

Plant Systematics and Evolutionary Science Division, Jawaharlal Nehru Tropical Botanic Garden and Research Institute, Karimancode P.O, Palode, Thiruvananthapuram - 695 562, Kerala, India.

\section{Manuscript Info}

Manuscript History

Received: 19 December 2016

Final Accepted: 15 January 2017

Published: February 2017

Key words:-

Rotala, Lythraceae, Endemic species,

Peninsular India, Kerala

\begin{abstract}
The genus Rotala L., is represented by about 44 species and primarily distributed in tropical and subtropical regions. In India, the genus has represented by $66 \%$ of the globally known species and among that $83 \%$ are remarkably endemics which show its evolutionary significance. The study on this genus led to discuss a novelty to science, which has been collected from the lateritic plateau of northern Kerala, India. The species is similar to $R$. densiflora (Roth ex Roemer \& Schultes) and $R$. malampuzhensis R.V. Nair ex C.D.K.Cook, but differs from the former by having smaller habit (size), aristate bracteoles, clawed petals, and presence of nectar glands etc., and from the latter by its habit, trimerous flowers, shorter or absence of calyx appendage.
\end{abstract}

Copy Right, IJAR, 2017,. All rights reserved.

\section{Introduction:-}

The Genus Rotala L. (Lythraceae), has tropical and subtropical distribution and is represented globally by 44 spices (Mabberley, 2005), with highest distribution in tropical Asia (Cook, 1979). After Cook's revision, it is represented, as per the revised estimate, in India by 29 species, of which 24 are from the Peninsular India (Joseph \& Sivar., 1988, 1989; Pradeep et al., 1990; Mathew \& Lekshminarasimhan, 1990; Yadav et al. 2010; Prasad et al., 2012; Gaikwad et al., 2013; Prasad \& Raveendran 2013 a, b; Sunil et al., 2013; Anto et al., 2014; Ratheesh Narayanan et al., 2014; Lemiya \& Pradeep 2015). The authors collected an interesting specimen belonging to the genus Rotala $\mathrm{L}$. from the muddy substratum of drying depressions on the lateritic rocky areas of Kanayi village in Kannur District of Kerala, India. Detailed studies of these specimens revealed that it is distinct from all the known species of the genus and hence being described and illustrated as new species.

Rotala kanayensis Rijuraj, Rajendraprasad, Shaju \& Pandurangan sp. nov. (Figs. 1 \& 2).

Type: INDIA, Kerala, Kannur District, Kanayi village, $\pm 60 \mathrm{~m}, 9^{\text {th }}$ January 2017, Rijuraj, Rajendraprasad \& Shaju (Holotype, TBGT; Isotype, MH).

The new species $R$. kanayensis resembles Rotala densiflora in having erect habit, decussate leaves and calyx appendages, and $R$. malampuzhensis by decussate leaves, campanulate calyx tube and presence of nectar glands. It differs from the former by having smaller habit (size), aristate bracteoles, clawed petals, and presence of nectar glands and from the latter by its habit, trimerous flowers, shorter or absence of calyx appendage (Table-1).

Corresponding Author:- M.P. Rijuraj.

Address:- Plant Systematics and Evolutionary Science Division, Jawaharlal Nehru Tropical Botanic

Garden and Research Institute, Karimancode P.O, Palode, Thiruvananthapuram - 695 562, Kerala, India. 
Erect, marshy-terrestrial annuals. Stem single, to $15 \mathrm{~cm}$ tall, much branched at the tip, rooting from the nodes below, inconspicuously 4-angled below, strictly angled and narrowly winged on young branches, reddish when mature. Leaves simple, decussate, sessile, linear lanceolate to oblong, greenish, 1.5- $2.0 \times 0.3-0.5 \mathrm{~cm}$, base slightly cordate to amplexicaul, margin entire, reddish-tinged, apex obtused, midrib prominent below, canaliculated above, reddish when mature. Flowers solitary in axils, sessile, strictly 5-merous, $2-2.5 \times 1.5 \mathrm{~mm}$; bracts similar to foliage leaves; bracteoles linear lanceolate, slightly cordate at base and aristate at tip, $3 \mathrm{~mm}$ including $1 \mathrm{~mm}$ long arista, exceeding calyx tube. Calyx appendages narrowly triangular, tip acuminate, 1-1.5 mm long, longer than calyx lobes; calyx tube campanulate, $1.5-2 \mathrm{~mm}$ long, lobes broadly triangular, ca. $0.5 \mathrm{~mm}$ long. Petals 5, obovate, rounded at tip, 1-1.5 x 0.7-1 mm long, distinctly clawed, alternating with calyx lobes, bright pink. Stamens 5 , inserted at the base of the calyx tube with a pair of nectar glands, equalling to the level of calyx lobes, filaments $0.75-1 \mathrm{~mm}$ long, anthers 2 , globose, dorsifixed, nectar glands triangular, fleshy; ovary sub globose, sessile, 3-locular, trilobed, $1 \mathrm{~mm}$; style short; stigma capitate. Capsule sub globose, 3 valved, equal or slightly exceeding calyx tube, $1.5 \mathrm{~mm}$ long and $1 \mathrm{~mm}$ diam. Seeds numerous, semi ovoid, $0.3 \mathrm{~mm}$ long, bright yellow.

Flowering \& Fruiting: December-January.

Table 1:- Comparison of morphological characters of Rotala. densiflora, R. malampuzhensis and. R. kanayensis

\begin{tabular}{|c|c|c|c|}
\hline Characters & R. densiflora & R. malampuzhensis & R. kanayensis \\
\hline Habit & $\begin{array}{l}\text { Erect, amphibious or } \\
\text { terrestrial annuals, simple or } \\
\text { branched, } 50 \mathrm{~cm} \text { tall }\end{array}$ & $\begin{array}{l}\text { Tufted creeping annuals, to } \\
30 \mathrm{~cm} \text { tall }\end{array}$ & $\begin{array}{l}\text { Erect, branched, terrestrial } \\
\text { annuals, to } 15 \mathrm{~cm} \text { tall }\end{array}$ \\
\hline Stem & 4-angled, often winged & Terete, not winged & $\begin{array}{l}\text { Inconspicuously } 4 \text {-angled, } \\
\text { narrowly winged on tender } \\
\text { branches }\end{array}$ \\
\hline Leaves & $\begin{array}{l}\text { Sessile, ovate or elliptic- } \\
\text { oblong, apex acute to } \\
\text { acuminate, to } 2-2.5 \mathrm{~cm} \text { long }\end{array}$ & $\begin{array}{l}\text { Sessile, linear to lanceolate, } \\
\text { greenish, apex acute to } \\
\text { shortly truncate, to } 1.5 \mathrm{~cm} \\
\text { long }\end{array}$ & $\begin{array}{l}\text { Sessile, linear-lanceolate to } \\
\text { oblong, base codate to } \\
\text { amplexicaule, apex obtuse, } \\
1.5-2.0 \mathrm{~cm} \text { long }\end{array}$ \\
\hline Bracts & $\begin{array}{l}\text { Ovate or elliptic, } \\
\text { much shorter than foliage } \\
\text { leaves }\end{array}$ & $\begin{array}{l}\text { Linear-lanceolate, as long as } \\
\text { foliage leaves }\end{array}$ & $\begin{array}{l}\text { Elliptic, leaf like, as long as } \\
\text { foliage leaves. }\end{array}$ \\
\hline Bractioles & $\begin{array}{l}\text { Lanceolate-acuminate, } \\
\text { exceeding calyx }\end{array}$ & $\begin{array}{l}\text { Capillary, equalling calyx } \\
\text { lobe, } 1 \mathrm{~mm} \text { long }\end{array}$ & $\begin{array}{l}\text { Linear lanceolate lanceolate, } \\
3 \times 0.5 \mathrm{~mm} \text { long, exceeding } \\
\text { the calyx, arista } 1 \mathrm{~mm} \text { long }\end{array}$ \\
\hline Flowers & $\begin{array}{l}\text { Usually } 5 \text { merous, } \\
\text { occasionally } 4 \text { merous }\end{array}$ & Strictly 3 merous & Strictly 5 merous \\
\hline $\begin{array}{l}\text { Calyx } \\
\text { appendage }\end{array}$ & Longer than calyx lobe & $\begin{array}{l}\text { Shorter than calyx lobe, } \\
\text { sometime absent }\end{array}$ & Twice as long as calyx lobe \\
\hline Petals & $\begin{array}{l}5,0.5-1 \mathrm{~mm} \text { long, obovate, } 2- \\
\text { lobed at apex, pink }\end{array}$ & $\begin{array}{l}3 \text {, elliptic to oblong, acute at } \\
\text { apex, bright red }\end{array}$ & $\begin{array}{l}5 \text {, obovate, rounded at apex, } \\
\text { distinctly clawed at base, } 1- \\
1.5 \mathrm{~mm} \text { long, bright pink }\end{array}$ \\
\hline Stamens & $\begin{array}{l}5 \text {, rarely fewer, attached below } \\
\text { the middle of the calyx tube }\end{array}$ & $\begin{array}{l}3 \text {, inserted above the base of } \\
\text { the calyx tube }\end{array}$ & $\begin{array}{l}5, \text { inserted at the base of the } \\
\text { calyx tube }\end{array}$ \\
\hline Nectar glands & Nectar glands absent & $\begin{array}{l}\text { Nectar glands 3, prominent } \\
\text { alternating with stamens }\end{array}$ & $\begin{array}{l}\text { Nectar glands } 5 \text { pairs at base } \\
\text { of each stamen }\end{array}$ \\
\hline Style & Style as long as ovary & Sub sessile & $\begin{array}{l}\text { Shorter than half the ovary or } \\
\text { sub sessile }\end{array}$ \\
\hline Capsule & $\begin{array}{l}\text { Globose, } 2-3 \mathrm{~mm} \text { long, 3-4 } \\
\text { valved, }\end{array}$ & $\begin{array}{l}\text { Globose, longer than the } \\
\text { floral tube } 3 \text {-valved }\end{array}$ & $\begin{array}{l}\text { Subglobose, } 1.5 \mathrm{~mm} \text { long, } 3 \\
\text { valved }\end{array}$ \\
\hline Seeds & Semi ovoid, yellow & $\begin{array}{l}\text { Semi ovoid, bright red or } \\
\text { yellow }\end{array}$ & $\begin{array}{l}\text { Semi ovoid, smooth, bright } \\
\text { yellow }\end{array}$ \\
\hline
\end{tabular}

Distribution and Ecology:-

Rotala kanayensis is so far known only from the type locality, Kanayi, a laterite area in Kannur District. Significantly a small population occurs in the marshy substratum of a drying depression on the lateritic rock surface. Our observations confirmed that there are less than 50 individuals growing in the site of collection in association 
with Pogostemon deccanensis (Panigrahi) Press, Lindernia antipoda (L.) Alston, Lindernia tenuifolia (Colsm.) Alston var. tenuifolia, Drosera burmannii Vahl etc. It is therefore necessary to identify more areas of its occurrence towards planning further conservation measures as per IUCN guidelines and criteria (IUCN 2010, 2012); since it has been discovered now, Rotala kanayensis, could be categorized as 'Data Deficient (DD).

\section{Eponymy:-}

Rotala kanayensis is named after its type locality Kanayi in Kannur District, Kerala.
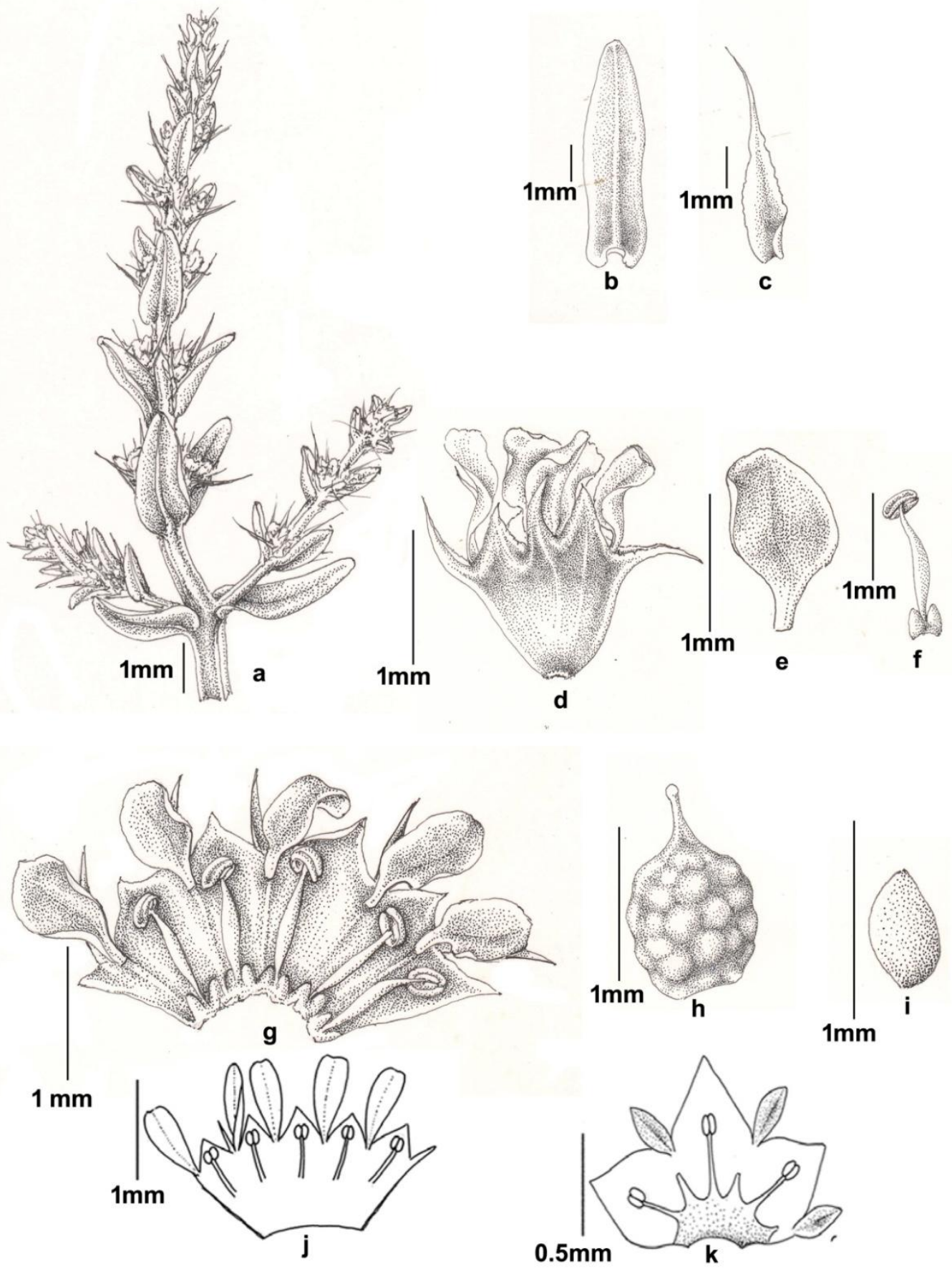

Figure 1. Rotala kanayensis. a. A portion of flowering twig; b. Leaf abaxial surface; c. Bractiole; d. Single flower; e. Petal; f. Stamen with a pair of nectar glands; g. Flower split open; h. Capsule; i. Seed; j \& K. Flower split open (Reproduced from Joseph \& Sivar., 1989): j. R. densiflora (Roth ex Roemer \& Schultes); R. malampuzhensis R.V. Nair ex C.D.K.Cook 


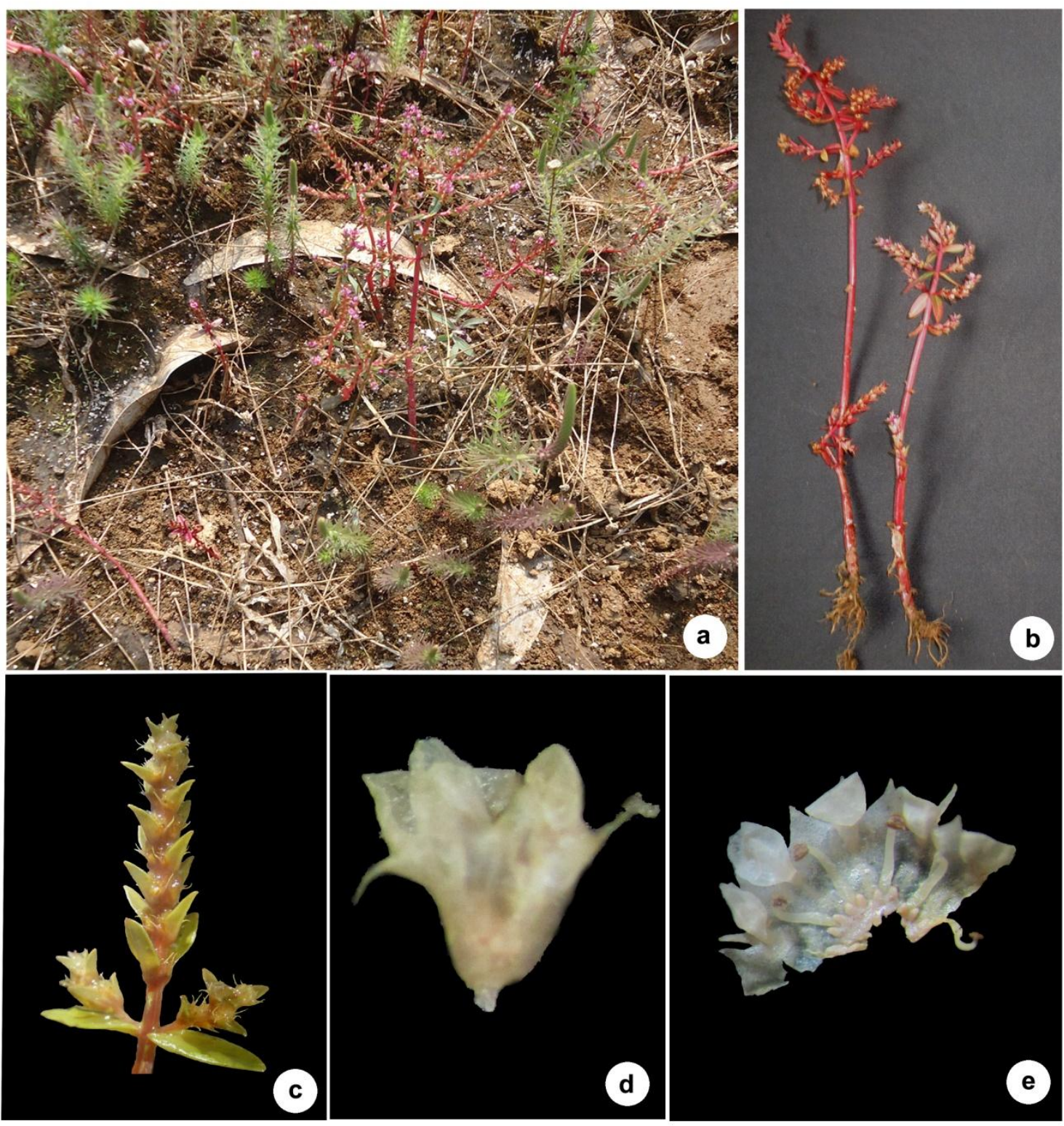

Figure 2: a. Habitat; b. Habit; c. Flowering twig; d. Single flower; e. Flower split open

\section{Endemism and habitat preferences of Rotala in Peninsular India}

The study on endemism provides an insight in to the centres of diversity and clues to the pattern of distribution and process of speciation. The evolutionary history of all endemics starts as neoendemics and end up as palaeoendemics (Richardson, 1978). Neoendemic species are newly evolved endemic species of relatively recent origin from an actively evolving genetic stock in a particular ecotone. They develop in different ecological niches or habitats through speciation and will have closely related taxa occurring in the same area. Neoendemics generally have herbaceous and shrubby forms and they occur in the areas that are prone to climatic and environmental stresses. All these factors substantiate the view that narrow endemism exhibited by the species of Rotala on the Peninsular India may indicate that they are neoendemics and the region can be considered as one of the centres of active speciation of the genus. The Peninsular Indian region has always been considered as an oceanic island in having conditions favourable for high degree of endemism (Turrill, 1964). 
Rotala is an aquatic or amphibious, tropical and subtropical genus with a considerable number of phenotypic plasticity (Joseph \& Sivar., 1988). Based on the nature of habitats, species of the genus Rotala falls under two groups, namely obligate aquatics which grow in shallow waters and semi-aquatic or terrestrials which thrive in marshy lands. Most of the species in Peninsular Indian regions are mainly distributed in amphibious ecosystems of lateritic plateau, especially in northern Kerala. Edaphic matrix of lateritic plateaus provides smaller scale habitats with hydro-geo-morphological anomalies that support significant plant taxa, especially endemics in restricted areas. The restriction of endemic plant species to nutritionally imbalanced substratum (laterite/serpentine) is a wide spread phenomenon in endemic rich areas. There is much evidence to suggest that this nutritionally imbalanced substrate provide a strong selective force for the evolution of endemic plants. In India, the genus Rotala is represented by 29 species, with their maximum morphological diversity in Peninsular India manifested by 26 species including 18 endemic taxa. Kerala is the major centre of distribution for the genus in Peninsular India with 21 species, in which 14 species are endemics, including 9 exclusive endemics. This highest degree of endemism of the genus is mostly represented from the lateritic zones of northern Kerala with very narrow distribution range. Endemics with extremely small range size, i.e. $<5 \mathrm{~km}^{2}$ are regarded as point endemics (Cowling, 2001), a category of narrow endemics. The analysis of distribution patterns of endemics gives a clear picture about the zones of their concentration and possible areas of active speciation. In this background an analysis of endemism in the genus Rotala L. in Peninsula Indian region with distribution status (IUCN, 2012) summarised in Table 02.

Table 02:- Distribution pattern of the genus Rotala L. in Peninsular India

\begin{tabular}{|c|c|c|}
\hline Peninsular Indian Endemic species & Haibtat & Distribution \\
\hline Rotala anamika Lemiya & Wet mashy area & Kerala * \\
\hline R. belgaumensis Yadav et al. & $\begin{array}{l}\text { Temporary pools in depressions on } \\
\text { lateritic rocks }\end{array}$ & Karnataka* \\
\hline $\begin{array}{l}\text { R. cookie Joseph \& Sivar. } \\
\text { (IUCN: Endangered) }\end{array}$ & Paddy fields, lateritic annual pools & Kerala* \\
\hline R. cheruchakkiensis Anto et al. & Laterite hilly area & Kerala* \\
\hline R. dhanesiana Sunil et al. & $\begin{array}{l}\text { Semi marshy areas in the moist } \\
\text { deciduous forest }\end{array}$ & Kerala* \\
\hline $\begin{array}{l}\text { R. fimbriata Wight } \\
\text { (IUCN: Least concern) }\end{array}$ & $\begin{array}{l}\text { Shallow water or marshes in lateritic } \\
\text { area }\end{array}$ & $\begin{array}{l}\text { Maharashtra, Karnataka, } \\
\text { Tamil Nadu \& Kerala }\end{array}$ \\
\hline $\begin{array}{l}\text { R. floribunda (Wight) Koehne } \\
\text { (IUCN: vulnerable) }\end{array}$ & Wet rocks & Maharashtra* \\
\hline $\begin{array}{l}R . \quad \text { illecebroides (Arn. exC.B.Clarke) } \\
\text { Koch } \\
\text { (IUCN: Least concern) }\end{array}$ & $\begin{array}{l}\text { Wet places and on dripping rocks in } \\
\text { hilly areas }\end{array}$ & $\begin{array}{l}\text { Maharashtra, Karnataka, } \\
\text { Tamil Nadu \& Kerala }\end{array}$ \\
\hline R. kasargodensis Prasad \& Raveendran & $\begin{array}{l}\text { Water logged soil on the lateritic } \\
\text { plateau }\end{array}$ & Kerala \& Karnataka \\
\hline R. khaleeliana Sunil et al. & $\begin{array}{l}\text { Temporary pools on the lateritic } \\
\text { plateau }\end{array}$ & Kerala* \\
\hline $\begin{array}{l}\text { R. malabarica Pradeep, Joseph \& Sivar. } \\
\text { (IUCN: Critically Endangered) }\end{array}$ & $\begin{array}{l}\text { Temporary pools in depressions on } \\
\text { lateritic rocks, }\end{array}$ & Kerala* \\
\hline $\begin{array}{l}\text { R. malampuzhensis Nair ex Cook } \\
\text { (IUCN: Least concern) }\end{array}$ & $\begin{array}{l}\text { Temporary pools on the lateritic rock, } \\
\text { paddy fields }\end{array}$ & $\begin{array}{l}\text { Maharashtra, Goa, Karnataka } \\
\text { \& Kerala }\end{array}$ \\
\hline R. meenkulamensis Prasad \& Ravi & $\begin{array}{l}\text { Temporary pools on the lateritic } \\
\text { plateau }\end{array}$ & Kerala* \\
\hline $\begin{array}{l}\text { R. ritchiei (C.B.Clarke) Koehne } \\
\text { (IUCN: Endangered) }\end{array}$ & Shallow margins of fresh water ponds. & $\begin{array}{l}\text { Maharashtra, Karnataka, } \\
\text { Tamil Nadu \& Kerala }\end{array}$ \\
\hline R. sahyadrica Gaikwad et al. & $\begin{array}{l}\text { Fresh water pool on the lateritic } \\
\text { plateau at high altitude }\end{array}$ & Maharashtra* \\
\hline R. tulunadensis Pasad \& Raveendran & $\begin{array}{l}\text { Temporary pools on the lateritic } \\
\text { plateau }\end{array}$ & Kerala* \\
\hline R. vasudevanii Joseph \& Sivar. & Fresh water pond & Kerala* \\
\hline
\end{tabular}

*Exclusive endemics 


\section{Acknowledgements:-}

The authors are grateful to the Director, Jawaharlal Nehru Tropical Botanic Garden and Research Institute (JNTBGRI), Palode, Thiruvananthapuram and to Dr. M. K. Ratheesh Narayanan, Associate Professor, Department of Botany, Payyanur College, Payyanur for various help in their research activities and field visit.

\section{References:-}

1. Anto,P.V., Jacob, C.S., Abraham, P., Varghese, C.D. \& I . Antony 2014. A new species of Rotala L. (Lythraceae) from the lateritic hills of Thrissur district, Kerala, India. Int.J.Adv.Res. 2(11): 532-535

2. Cook, C.D.K. 1979. A revision of the genus Rotala(Lythraceae ). Boissiera 29: 1-156

3. Cowling, R.M. 2001. Endemism. In: Simson, A.L.(ed.) Encyclopaedia of biodiversity. Academic Press, 2: $497-$ 50.

4. Gaikwad, S.P., Sardesai, M.M \& S. R. Yadav 2013. Rotala sahyadrica sp. nov. (Lythraceae) from Western Ghats, India. Nordic J. Botany 32 (5): 575-577

5. IUCN. 2010. Guidelines for using the IUCN Red List Categories and criteria: Version 8. Prepared by the standard and Petitions Subcommittee, Available from: http://www.iucnredlist. org.

6. IUCN. 2012. Red List Plants of India. IUCN Red List of Threatened Species. Version 2012.2. www.iucnredlist.org.

7. IUCN. 2014. Guidelines for using the IUCN Red List Categories and criteria: Version 11. Prepared by the standard and Petitions Subcommittee, 87 pp. Available from: http://www.iucnredlist. org.

8. Joseph, K.T. \& V.V.Sivarajan 1988. Rotala cookii: A new species of Lythraceae from India showing Hippuris Syndrome. Plant Systematics and Evolution 159: 141 -144

9. Joseph, K.T. \& V.V.Sivarajan 1989. Rotala Linn. (Lythraceae) in peninsular India. Proc. Ind.Acad.Sci. (Plant.Sci.) 99:179-197

10. Lekhak, M.M \& S.R.Yadav 2012. Herbaceous vegetation of threatened high altitiude lateritic plateau ecosystems of Western Ghats, Southern Maharashtra, India. Rheedea 22 (1): 39 - 61

11. Lemiya, K.M. \& A.K.Padeep 2015. A new species of Rotala (Lythraceae ) from Kerala, India. Rheedea 25: 159-163

12. Mabberley, D.J. 2005. The Plant Book. - Cambridge Univ. Press

13. Mathew, S.P. \& P. Lekshminarasimhan 1990. Rotala andamanensis - a new species of Lythraceae from Andaman Islands, Bull. Bot.Surv. India 32: 189 - 191

14. Pradeep, A.K., Joseph, K.T. \& V.V. Sivarajan 1990. Rotala malabarica, a new species of Lythraceae from India. Botanical Bulletin of Academia Sinica 31: 59-61

15. Prasad, K.S., Biju, P., Raveendran, K. \& K.G. Bhat 2012. Rotala thulunadensis sp. nov.(Lythraceae) from Kerala, India. Nordic J. Botany 30: 59-60

16. Prasd, K.S. \& K. Raveendran 2013a. A New species of Rotala L. (Lythraceae) from Kerala, India.Taiwania 58(2): 104-107

17. Prasad, K.S. \& K. Raveendran 2013b. Rotala kasaragodensis (Lythraceae), a new species from Kerala, India. Edinburgh J. Botany 70(3): 451-454.

18. Ratheesh Narayanan, M. K., Sunil, C.N., Shaju, T., Nandakumar, M. K., Sivadasan,M. \& A. H. Aifarhan 2014. Rotala dhaneshiana, a new species of Lythraceae from India.Phytotaxa 188 (4): 227-237

19. Richardson, I.B.K. 1978. "Endemic Taxa and the Taxonomist" In: Street, H.E. (ed.) Essays in Plant Taxonomy. pp.245-262. Academic Press. London

20. Sunil, C.N., Ratheesh Narayanan, M.K., Nandakumar, M.K., Jayesh, P.J., Abdul Jaleel, V. \& N. Anil Kumar 2013. Rotala khaleeliana sp. nov.Lythraceae), a new species from lateritic hills of Kannur, Kerala,India. Int.J. $A d v$. Res. 1(2): 14-16

21. Turril, W./B. 1964. Plant Taxonomy, Phytogeography and Plant ecology. In: Vistas in Botany, vol. IV Pergamon Press. London

22. Yadav, S.R., Malpure, N.V. \& A.N.Chandore 2010. Rotala belgumensis (Lythraceae) from the Western Ghats, India. Nordic J. Botany 28: 499-500. 